\title{
Quran Objective Solutions to Meet the Needs of Modern Man
}

\author{
Ibrahim Kalantari ${ }^{1}$ \\ ${ }^{1}$ Faculty of Maaref and Islamic Thought, Department of Islamic Maaref, Tehran, Iran \\ Correspondence: Ibrahim Kalantari, Faculty of Maaref and Islamic Thought, Department of Islamic Maaref, \\ Tehran, Iran. E-mail: ekalantari@ut.ac.ir
}

Received: January 21, 2017

Accepted: January 23, 2017

Online Published: May 16, 2017

doi:10.5539/res.v9n2p286

URL: http://doi.org/10.5539/res.v9n2p286

\begin{abstract}
The author attempts in this paper to search for objective solutions of meeting Quran focused on human needs, and followed a logical sequence of the discussion. This paper is organized in two parts: the first part reviews and explains human needs from the view of religious scholars and psychology scientists and in the end, lists all types of human needs. The author of this section studies the situation of modern human needs. Which objective solutions, The Quran introduce to respond humanitarian needs, especially contemporary man?

The second part that has more volume reviews and explains the objective solutions of the Qur'an to meet human needs. The author of this article, due to the limited scope of this article, considers many of these solutions briefly.
\end{abstract}

Keywords: Quran solutions, physical needs, psychological needs, spiritual needs, the modern man

\section{Introduction}

There is no doubt that a new era has posed the human with startling transformations. Science and technology as two major achievements of the new era: Firstly, has changed the lifestyle completely and as a result has created a new form of urbanization and a new life. Secondly, has changed the human relationship with his fellow humans in the form of new forms. Thirdly, human has conquered the nature with all properties.

Through each of these events, hundreds of new issues have been created in the mind and human life, that a peer review and adopting reasonable positions for each one is modern imperatives of our time, which in turn are very complex and filled with elegance. Theoretical and practical positions of a Muslim man, in the face of these problems, are also risky on the other hand, and that is the accuracy in matching or at least not conflicting of positions with the original teachings of Islam, as a religion.

A Muslim has always tried based on his belief and religious practice, to find any theoretical and practical confrontation with new issues based on Scripture and tradition, as the basis of authentic religion, and thereby, flow the religions in his living space. Certainly, such an approach will make dealing with new issues more complex and more difficult to achieve a comprehensive response.

"Holy Quran objective solutions to meet the needs of modern man" happens in such a place and wants to refer to the Quran, to find a solution that is adapted to the needs of modern humans objectively and provides the field for a comprehensive plan to "live in the light of the Holy Qur'an".

This article is organized to explain further discuss on the issue and follow a logical sequence, in two parts: 1) Explaining the needs of man and physical and spiritual bases. 2) Explaining the objective solutions of the Quran to meet the needs. We hope that this article will be an introduction to get to the comprehensive plan, in which all aspects of the Quran objectively meet the needs of modern man, is considered.

\section{Human Needs}

Needs and wishes arising from life and human life are the main cause of different laws and regulations that have emerged since the beginning of human life on earth (See: Tabatabai). There is no doubt that a human is a needy person in terms of his existent structure, however, about the matter that these needs come from which aspects of his existence, needs a lot of research. Scholars from different fields, based on their expertise and field of study, have expressed and categorized the subject of human needs and their origins.

What this article is taken into consideration is reviewing and explaining human needs from the perspective of religious scholars and then from the perspective of psychology scientists, because with a clearing hierarchy of 
human needs, way of reviewing and explaining the objective solutions of Quran responding to meet those needs will also be paved.

\subsection{Human Needs from the Perspective of Religious Scholars}

Many religious scholars, including Allameh Seyyed Mohammad Hossein Tabatabai (Ibid., 1414, Vol. 4, No. 2), Seyed Qutb (Qutb, 1402, Vol. 1), Morteza Motahhari (Motahari, 1998, p. 1; Ibid.), Jafar Sobhani (Sobhani, 1993), Mohammad Hadi Marefat (Marefat, 1995, Vol. 3), Mohammad Taghi Mesbah Yazdi (Mesbah Yazdi, 2009, Vol. 3), Seyed Muhammad Baqir Sadr (Sadr, 1424) and Rashid Reza (Rashid Reza, Vol. 7) have researched and commented about the human needs. The common denominator of the investigation is trying to explain, how to respond Islam as the final religion, to the changing needs of human beings and this matter has been caused, each one reviews and categorizes the human needs.

"The issue of how the fixed religion responds to the changing needs" has found critical importance in the past one hundred years, due to significant changes in the field of human life, and has become the fundamental issue in various fields of religious thought, for this reason the religious studies of scholars have been paying attention to it widely.

1) Allameh Tabatabai: From Allameh Tabatabai's point of view, the purest and most stable of human being aspect that is a fixed feature of his existence, is the humanity of a man. This feature is the common value to all human races in all ages and generations that in the first place, it creates a series of common needs that depends on the common legislation (Tabatabai, pp. 31-32).

The need to protect the life, eating, drinking, sexual instinct, clothing, housing, different emotions (love and hate, fear and hope), searching and thinking and etc. are common needs of people who have never changed. The "constant needs" want fixed rules that are common in all ages and for all generations (Ibid.).

On the other hand, humans have other needs in their life that with the progress of civilization, these needs gradually will be met and new needs will be replacing them. These "changing needs" also want changed rules (Ibid., p. 29) that a clear mechanism for the correct response to them have been seen in the context of religion. Some other scholars "common nature" have known a man as the oneness of the human race in all ages and based on it, they have believed a series of "fixed needs" and "common" in all human beings (Sobhani, 1993, pp. 296-298; Sayyid Qutb, 1402).

2) Motahari: He, in counting human needs, although in the basis, has a similar view to his professor Allameh Tabatabai, he uses a different approach to divide needs. He divides the human needs into two groups: primary and secondary. He knows the primary needs, the needs that originate from the depth physical and mental structure and from, human social life, nature, so that, as human beings are a human and as his life is social, these needs are persistent and unchangeable (Motahari, 1998, p. 49).

Motahari categorizes the primary need into three sections:

-Physical needs, such as food, clothing, housing, wife, etc.

-Spiritual needs, such as science, beauty, goodness, worship, respect and education.

-Social needs, such as socialize, exchange, cooperation, justice, freedom and equality (Ibid., pp. 49-50). The master knows the secondary needs, the needs that arise from the primary needs, such as the need to a variety of tools and equipment of life that differ at every age (Ibid., p. 50).

He said about the fundamental difference of primary and secondary needs: the primary needs area human stimulus to the development and evolution of life, but the secondary needs are resulting from the development and evolution of life and at the same time, they are stimulating the further development and higher perfection (Ibid.). Motahari has reviewed this issue from the perspective of "Attraction" and human elasticity and has divided the attract into two groups (Ibid., pp. 19-27).

A) Natural and material attractions and elasticity: the desire for food, desire to sleep, sexual desire, the desire for rest and relaxation, and so on that draw a man to the substance and nature, are in the category of attractions (Ibid., p. 19).

B) Attractions and spiritual elasticity: These types of attractions draw a human toward immaterial centers, meaning the things that have no volume, and no weight and are not measurable with material things (Ibid., p. 20). The spiritual attraction list that has been recognized until now, and has been approved by scientists, is as follows: 
-Science and knowledge: the human has the truth seeking and researching instinct, which means that self-knowledge and awareness for human is desirable and enjoyable, even if it has no influence on his material life (Ibid.).

-Moral goodness: Humans do many things for "moral values"; not for material things. This is the coordinates of human and relates the spiritual aspect and elasticity of his metaphysics (Ibid., pp. 21-22).

Interest in beauty forms an important part of human life; so that this spiritual elasticity will emerge in all aspects of his life (Ibid., pp. 22-23). Sanctification and worship: one of the most stable and oldest strains of the human soul is a sense of sanctification and worships that form one of the purest aspects of human existence (Ibid., pp. 23-25).

3) Martyr Sadr: martyr Muhammad Baqir Sadr, also by citing the fixed and variable provisions In Islam, knows this change and stability affected by the existence of fixed and variable needs (Sadr, 2006, p. 69, pp. 101-102). In his view, fixed needs are come from human nature, and because human has two material and spiritual aspects in his nature, so his fixed needs are divided into two parts of material and spiritual (Ibid., 1424, p. 75). A need to a partner and to provide material life and so on are including material fixed needs and the need to connect with God, personal and social freedoms and the like this are considered as including spiritual fixed needs.

4) Professor Mesbah Yazdi: He commented on this matter with more delicate and from different angles (Mesbah Yazdi, 2009, pp. 412-419). He categorized wishes and desires of human beings according to his look in three broad categories:

A) The inner desires, including: (1) Instincts, such as the instinct of eating, drinking and sexual instinct. (2) Emotions such as parents' affection to their child and spiritual emotion of a teacher to student. (3) Passions, such as hatred, anger and rancor. (4) Emotions, such as feelings of surprise, istihsan, honor and love (Ibid., pp. 213-215).

B) Inferior demands, including a series of animal demands, such as Sensuality, gluttony, preventing kindness, greed, loves of the world (Ibid., pp. 216-217). Higher demands that are higher than the animal demands, such as loving personality, searching independences, the desire to survive, and above all, especial final desire in the deepest part of a man to God (Ibid., pp. 217-220).

In his view, the human desires and needs can be divided from other people point of view:

1) What that has physical and physiological aspects. 2) What that has a psychological aspect, but is low mental needs, like joy and relaxation. 3) What that has psychological aspect, but is great mental needs, such as idealism, seeking freedom and so on. The group of needs that can be called, as "noble human ideals" are four categories:

(1) Seeking right, meaning the recognition of the facts. (2) Wanting virtue, such as justice, freedom and so on. (3) Seeking beauty, meaning the absolute beauty that human interest belongs to them that some are related to the sights, some so the hearings, some to the imagination and so on. (4) Religious sense that is a demand within a wide trilogy and, according to some, these three are within a radius (Ibid., pp. 220-221).

\subsection{Human Needs from the Perspective of Psychologists}

Psychology is a science of "scientific study of human behavior" (Witig, 2007, p. 13). Discussion of human needs in this knowledge is concerned through the lens of human behavior, because they know the human needs as the source and guiding his behavior (Carver, 1996, pp. 182-184). Among psychologists who have argued about the hierarchy of human needs, scientists such as Carl Rogers, Abraham Maslow (Khodapanahi, 2008, p. 192), Clayton Alderfer and Frederick Herzberg (Schultz, 2007, p. 376) can be seen, but Maslow's theory in this regard is perhaps the clearest and most comprehensive statement. According to this theory, all human behavior is stemming from a series of needs that form "hierarchy of needs". Maslow has divided these needs into three general groups.

\subsubsection{Existential Needs}

A number of inherent requirements that enable and guide the behavior of each individual, are instinctive, it means every human being is born with them. One of the features of these public needs is their placing in a hierarchical order of importance (Ibid., p. 361). This group of needs from the bottom to up is as follows:

1) Physiological needs, like the need for food, water, air, the opposite sex and sleep. 2) Safety needs, such as the need for security, order and stability, support and freedom from fear and anxiety. 3) Needs of belonging and love, such as: friendly relationship with others, belonging to a peer group... 4) Esteem Needs: emerges in the form of self-esteem and respect from others. 5) Self-actualization needs: to fulfill their potential capabilities that will be their turn after meeting the previous needs (Ibid., pp. 362-366). 


\subsubsection{The Cognitive Needs}

This group of needs also rooted in human nature and draw human behavior toward things and activities. Curiosity, need to know, need to understand and find meanings in life are in the hierarchy of human cognitive need (Ibid., pp. 366-367).

\subsubsection{Ultra Needs (Existential Values)}

After meeting the existential needs and reaching people to the stage of "self-actualization", another group of needs (only for these people) appear that are objectives itself, not a means to achieve other goals (Ibid., p. 369). Maslow calls these needs to "Ultra needs" or "existential values" and believes that ultra needs are behaved like needs and unfulfilled the mis harmful, such as the inability to satisfy every lower level need that is harmful (Ibid., pp. 369-370).

From Maslow's point of view, the need for truth, goodness, unity, integrity, fairness, integrity, beauty, goodness, meaningfulness (as opposed to despair and meaninglessness), simplicity are considered as ultra needs (Ibid., p. 371). The last effect of the actuality of human nature that Maslow has witnessed, is "peak experience" that know it in the latest speculation, as the highest degree of self-actualization (Abu Torabi, 2007, p. 87).

\subsubsection{Summing Up the Views on the Needs}

The first and most obvious point is "principle of need" for human being. The need is a part of human nature. That is why the true image of man without his needs can never be achieved. Human needs can be divided into three groups according to his existential dimension:

1) Needs resulting from the material and physiological aspect of human: the need to eat, drink, clothes, sex, sleep, air, shelter and what Maslow has raised as existential needs are in this category.

2) Needs resulting from the mental aspect of human: the need for happiness, security, peace, freedom, cooperation, self-esteem, affection, anger and hatred, self-actualization, curiosity, knowledge and understanding are in this category.

What Professor Mesbah Yazdihas risen as "mental nozzle needs" or Motahari has risen as "social needs" and Maslow called "cognitive needs" are placed in the same group.

3) Needs arising from the human spirit: the need for truth [seeking right], wanting virtue, a sense of seeking beauty, a sense of worship and what Professor Mesbah Yazdi has risen as "mental high needs" or Maslow has called "Ultra needs" are all fit in the same group.

Above needs have come from the depths of human existence, because they are fixed and do not change in any way different generations. What changes in the current time from one generation to another or from age to age is only some of the methods and forms of responding to human needs.

For example, to meet the constant need to eat for humans may provide in an age in the form of vegetarianism, and in the other age in the form of Raw Vegan, cooked dishes and combination, as each way may have various forms in its era. About the need for housing, methods and problems responding are diverse in the context of the time. In providing happiness, peace and security, the need to understand and most tangible and inclusive of the needs, realities of the diverse forms and methods in meeting them, show in different ages and generations.

In the response to the need for truth [seeking right] that is the spiritual needs of man, has emerged a variety of ways and methods and study on the horizons and study in the souls of scientific, philosophical and mystical represent this diversity. A sense of worship that is considered the spiritual needs of human beings has always been constant in time, but the methods and forms of responding to it in the context of the time are faced with many changes. So what happened human needs is in two kinds: 1) constant needs of physical, mental and spiritual, 2) changing needs of the methods and practices, to provide constant needs and meet the new requirements.

\section{Modern Human and His Needs}

Modern humans can be found in two very important areas, distinct from the old man's age: 1) In Cognition area; 2) In the technology area. The modern humans score in these two areas has helped: First, the universe will be displayed much wider and more complex than before. Secondly, this power is given to him that in many new areas, such as space, heavenly spheres, deep in the oceans, deep in the earth, the Antarctic and..., to have effective presence. Thirdly, it has helped him to create new forms of communication with tools such as press, radio, television, satellite and the Internet (Sheriff, 2003, pp. 328-329).

Emerged development collection in the minds and lives of modern humans through recognizing and technologies has had two achievements: 
-It has given methods and new forms to meet the needs of physical, mental and spiritual.

-It has given a long list of issues and new problems that were not in human life of old age. For example, when modern humans can conquer the moon, this new problem has occurred to him that, on the moon, to which direction he should pray, or because he has earned the simulation ability, dozens of new legal issues have been raised for him.

Anatomy of a dead body, vitro fertilization, and organ transplants from living to alive or from dead to alive, global trade, new types of terrorism, bank, insurance and dozens of other new issues, all are in this group. On this basis, the modern human with old age human have essentially fixed needs of physical, mental and spiritual, and what has changed as follows: 1) The emergence of new methods and practices that serve people's needs. 2) The emergence of new issues and developments which seek to identify the man in this era.

\section{Solutions of the Quran Are Responding the Needs}

The Quran is a book of guidance (Baqarah, p. 185; Qesas, p. 43). For this reason, its verses are objective responses to human needs on the path to ultimate perfection. Comprehensive look at the Quran verses and detailed study of the teachings and its guidance from the perspective of human needs, gives us the fact that the Quran has released two groups of objective solution to meet human needs:

\subsection{The Objective Solutions Based on Fixed Needs of Man}

Earlier, we have categorized the fixed needs of human into three groups (physical, mental and spiritual). Now to fit the need, we are reviewing and explaining the Qur'an verses.

1) Objective solutions based on material needs:

First. The first human physical need is eating, drinking, and his material survival depend on its realization. The first message of revelation in this regard: "One must think to his food and nourishment to the eye of wisdom" (Abas, p. 24). Certainly, the reason to consider this verse is not superficial glance, because it is necessary: 1) to know what he should bring home to prepare food; 2) how to cook; 3) how to eat; 4) when to eat; 5) where to eat; 6) what to eat; 7) with whom to eat; 8) in what to eat; 9) how much to eat (Paknejad).

In various verses of the Quran, it emphasizes on eating the food that has two conditions of "Halal" and "purity": "O people, eat of what is halal and purify in the earth" (Baqarah, p. 168; Maeda, p. 88; Nahl, p. 114). As well as in other verses, it has introduced animals (Nahl, p. 5; Anaam, p. 142), aquaculture (Nahl, p. 14; Maeda, p. 96) and plant and agricultural products (Abas, pp. 27-32; Nazeat, pp. 31-33) as human food sources. On the other hand, water (Anbiya, p. 30), milk (Nahl, p. 66) and Honey (Nahl, pp. 68-69) are introduced as drinking and life-giving resources for human.

The Qur'an puts positive solutions, some negative solutions in the field of eating and drinking before human beings. Forbidding man from eating carrion, blood and pork (Maeda, p. 3) and drinking alcohol (Baqarah, p. 219) which have inherent dignity, also avoid eating meat from an animal that had been slaughtered or strangled in the name of non-God or dead by hitting or disease, or has fallen from a height, and died or has killed by hitting horn or dead by a wild animal or its head is cut off in front of the idol, (Ibid) that have inherent dignity, or what has gained from the usury way (Baqarah, p. 275) or has provided by rubbery (Nisa, p. 29) are in this category. In many verses of the Holy Quran has forbidden the extravagance in eating and drinking (Araf, p. 31; Anaam, p. 141; Nisa, p. 6).

Second. Clothes are the basic human needs. As far as history shows that people always wore the dress (Cox, 2007, p. 5). Holy Quran asserts two important benefits of clothes: 1) Maintain genitals and adorn it, "O children of Adam, we sent you a garment to wear your genitals, as well as adorn garment and garment of piety" (Araf, p. 26) and "O Children of Adam, when you pray, Wear your clothes...." (Araf, p. 31). 2) Its protection aspect against heat and cold, "Shirt that will keep you from the heat" (Nahl, p. 81), "Sarabil" is the plural form of Sarbal, meaning shirt, although some commentators know it any clothing (Makarem Shirazi, 2002). In addition the Holy Quran also mentioned the two main sources of supplying clothes, meaning the animals (Nahl, p. 5) and vegetable (Abas, pp. 26-32; Nazeat, pp. 30-33) and prohibited the waste of clothing consumption (Araf, p. 31). The Quran also commanded the believing women to avoid the lusting glances revealing the decoration and covering the head, neck and chest in front of non-mahram men (Noor, p. 31; Ahzab, p. 59).

Third. The sexual instinct is the strongest and indomitable inherent instincts of human, as such, require the opposite sex is considered one of the basic human needs. Quran knows the marriage as the only correct way to respond to this need, and said: "Marry your single men and women, as well as your righteous slaves; if they are poor, Allah will enrich them from His bounty, and Allah is Aware!" (Noor, p. 32). Because a permanent marriage for those who have reached the age of marriage, is not always possible, the Quran, to prevent the diversion of the 
sexual instinct has put in front of the believers two basic strategies: 1) observing chastity and piety: "and those who cannot find marriage tool, should have chastity and piety" (Ibid., p. 33). 2) Temporary marriage (Nisa, p. 24).

The Quran has given many recommendations to keep sexual instinct and control it in the right direction (Mu'minun, pp. 5-6; Noor, pp. 30-31; Ahzab, p. 35; Ma'arij, p. 29), and has known the adultery as a very ugly and vain action, adulterers deserve punishment (Noor, p. 2) and sodomy is placed like adultery in a row and a clear deviation from the right path of sexual instinct (Nahl, pp. 54-55; Spider, pp. 28-29; Araf, p. 108).

Fourth. The need for housing is as the material needs of human beings. Housing, from the "Sakan" means stability, establish and peace (Ibn Manzur, 1996, the following term housing). Proper housing should be the supplier of the safety and security of its residents are physically and mentally. The Quran also knows the houses that bring peace and the residence to the people, as the blessings of God and says: and God made your houses as a resident (and peace) place and made houses from the skin of animals that you can move them easily for the day of immigration and on the day of your stay... (Nahl, p. 80).

In the Holy Quran, the establishment of man on earth is this purpose so they can have luxurious palaces and strong homes from plateaus earth and mountains: On the ground that in the plains build mansions for you and carve homes in the mountains for themselves! So remember the favors of God and do not do corruption on earth (Araf, $p$. 74). On the other hand, a proper housing in the Quran, should have the walls to protect its inhabitants against the enemy: Some of them asked the Prophet to return, saying our houses are unprotected, while not exposed, they just wanted (the war) to escape! (Ahzab, p. 13).

Quran recommended the moderation and avoidance of waste in the housing, and in the following verse, said from Prophet Hud language, in his criticism of some of the construction waste: is on every tall place, build a Cued house, while you do waste (Shoara, p. 128), and says in the following: and choose strong palaces, so maybe you (in the world) remain immortal (Shoara, p. 129). To be sure, the principle of proper and strong housing is not denounced these verses, but neglecting the Hereafter because of luxury worshiping and uncalculated fixing in palaces and mansions so that the world will be a permanent abode in their look, is to blame (Tabatabai, 1414; Makarem Shirazi, 2002).

2) Objective solutions based on psychological needs:

List of most human psychological needs was discussed in earlier pages. Now we explain the objective solutions of the Holy Quran on the most important psychological needs. First. The need for security and mental peace is considered one of the most basic human needs. Schools of psychotherapy, in response to this basic human need, have provided a range of methods and strategies that perhaps in practice, are not associated with success. However, checking the history of religions, especially Islam shows that faith in God has been quite successful in fulfillment of Security mental peace and the prevention of anxiety and psychological diseases caused by it (Nejati, 2007, pp. 367-368).

Unlike schools of psychotherapy, which after human exposure to anxiety and mental illness will treat him, faith in God, if in real meaning will be established in human existence, creates a kind of immunity and prevention of mental illnesses. The Holy Quran clearly states this fact that: Those who believe and did not contaminate their faith with wrong and cruelty, safety id only for them and they are guided (Anaam, p. 82). In another verse we read: Those who believe make peace for your hearth with praying God (Raad, p. 28).

The Holy Qur'an considers the faith as a prevention of any kind of fear and sadness (Baqarah, p. 112; Fosselat, pp. 30-31; Ahghaf, p. 13). True faith in God makes the human strong against temptations and vicissitudes hard life (Hadid, pp. 22-23), makes the death easy in his eyes (Feslat, pp. 30-31) and confession of sin and ask forgiveness from God as a means to increase hope (Dahr, p. 53) and more guidance and closeness to God (Taha, p. 82).

The Holy Qur'an knows faith in God as the only means to achieve psychological security, and provides a specific and applicable solution for psychotherapy of psychiatric patients. The solution that is a combination of both theoretical and practical parts is clarified in many verses of the Qur'an clarified (Nejati, 2007, pp. 382-415).

Second. The need for happiness is the needs of the human psyche. Happiness is a relative thing, which means that, it is based on achieving the goals, aspirations and demands that man has outlined in his life. If a person achieves is purpose, or favorable desire, he feels a state of joy and happiness in himself. In the Quran, human happiness is two kinds: transient happiness and lasting and profound happiness. The first one is arising from reaching the world objectives minus attention to the hereafter and with authentic look to worldly life. In this regard, the Quran says People are pleased with world life, while the worldly life has less enjoyment than the life hereafter (Raad, p. 26).

A feature of such joy is its instability in the Quran: and if we give a blessing to the people from our side, then take it from him, he becomes desperate and hopeless. If after some misfortune has reached him, give him blessings, he 
says the problems were finished, and they will not come back and rejoice and neglect and bragged (Hood, pp. 9-10). The second type of happiness from the Holy Quran view is created by faith and good practice of targeting and focusing on life in the hereafter: Everyone, male or female does a good deed while has faith, undoubtedly we (in the world) will give him a clean life to live and (in the Hereafter) will give him reward for their good practices (Nahl, p. 97).

The pure life concept is very broad. Cleaning of dirt, cruelty, treachery, enmity, bondage, humiliation and all of the concerns and whatever makes the water of life bitter on the palate of man, is within the broad concept (Makarem Shirazi, 2002). In expressing the martyrs of God, Holy Quran describes them rejoice in what Allah has bestowed upon them (Omran, p. 170).

In addition, in expressing the Prophet (pbuh) etr at bonuses, that to satisfy the God, gave his food sincerely to the poor, the orphan, and the prisoner, he speaks of a heavenly deep joy and happiness (Ensan, p. 11). Based on the above strategy, the objective approach of the Quran on human happiness is "guidance and direction to it in the path of faith and good deeds and sustainable ideas afterlife".

Third. Need for affection and love is the need of the human psyche. The need for love and affection will emerge in various forms of human existence, relationships with other, relationship with special friends [child and spouse] or position in a particular group or society as a whole (Schultz, 2007, pp. 364-365) also relation to material things or spiritual or abstract concepts.

On the other hand, the need for affection and love is bidirectional matter, which also includes the supply of love and receives it. Because love comes from human nature and it flourishing realizes spontaneous and instinctive, the Holy Quran followed the adjustments and suggests a positive direction. In the Holy Quran view, the most visible form of this mental features will emerge in "excessive self-love" that, its effect is fear and aching when plight, greed in acquiring wealth and position in the world and meanness and avarice when reaching the wealth of the world. Quran knows the way to alleviate this extreme love, in faith in God, prayer, zakat and alms to the poor and faith in the Resurrection and the compassion of Divine retribution (Ma'arij, pp. 19-27).

Allah, in the Qur'an, knows the love borne out of faith, of the highest forms of love, and he created it: Believers who are led to victory. He attuned love in their hearts. If you spend on earth, you could not have all of their hearts, but Allah attuned love. Lo! He is Mighty (Anfal, pp. 62-63) Quran knows love and mercy between spouses as forging developmental effect of God (Rom, p. 21).

Some forms of love and affection in secularist look has the beauty and great charm, such as love desires of women, children, much of gold and silver, and horses privileged property, livestock and agriculture. Quran disapproves the extreme interest in the worldly beauty and in contrast, encourages what is in the supply route of the Hereafter (Ale Emran, p. 14). Paternal affection also approved by Quran to the extent that is not in conflict with true faith and love of God (Hood, pp. 45-46).

Holy Quran in order to correct direction to the inherent power of love and affection of men introduces the highest, perfect, and purest kind of love as the believers' love of the God: Some people choose peer for God and they loved it, but those who believe, love God more (Baqara, p. 165; Emran, p. 31; Maeda, p. 54; Tobe, p. 24).

Fourth. The need for science, knowledge and understanding is another part of the basic human needs. As mentioned above, some intellectuals put this need in a row of the great spiritual needs and some put it between existential and ultra needs. It is obvious that, the need stems from the depth of human existence and to achieve it, has a value equals to faith in Quran view (Mojadeleh, p. 11).

Because, this need in human comes from the unique inherent capacity and power. Many verses of the Quran, clearly, included the manipulation of this power in the direction of recognizing and understanding the reality of existence, origin, the resurrection and purpose of existence. Several tools are embedded to achieve basic needs in human existence that some are sensitive and rational.

In the Holy Quran, not to use these tools to achieve correct understanding of the realities of existence, decline one from his high position in existence and puts him in an inferior position than animals: The worst of animals before God are the deaf and silence who does not think (Anfal, p. 22). We have created many jinn and human for hell, they have heart that does not understand, and eyes that could not see and ears that do not hear, they are like animals even more misleading than they are, they are heedless (Aaraf, p. 179).

In the Quran, in parallel with the embedded tools for knowledge in human existence, there are various signs placed in the universe, so that the real understanding happens correctly by a human being, "Soon we show our signs in the horizons [the various] and in their hearts, so that it will be clear to them that he is right" (Fosslat, p. 53). 
Science, knowledge, and understanding of the Holy Quran verse are so important that hundreds of verses-direct and indirect-talked about it. 135 verses, call a man to "think", "intellection", "contemplate", "Education of pure reason", "consciousness" and "great understanding". These verses, and the attachment of verses about the need to address the knowledge have spoken indirectly, more than three hundred verses of the Qur'an are included (Jafari, 2005, p. 223).

3) Objective solutions based on spiritual needs:

Spiritual needs are the highest type of human needs, that it may be known as the main indicator to distinguish humans from other creatures. This section has been allocated observing briefly, the explanation some of the Quran ways, in responding to some of these needs.

First. Seeking beauty is a surprising and important feature of the human spirit, which has different levels; some appearance levels are deep and come from tangible beauties and pleasure and mental expansion, which will be obtained from perceiving them, and some of its levels are deep and derived from rational and spiritual beauty (Ibid., p. 180). The first point that we can find the concept of beauty in the Quran is that the Quran relates the beauty of existence to God and rebukes the depriving of the people from them: "Who has forbidden the clothes that God has created for His servants" (Aaraf, p. 32).

Although the beauty of the universe is the two types, a group that has been created normally based on the creation and the group that has been created with thought and taste and human effort. However, the reason that all of them attributed to the Lord is in verse, that created beauty by man, also will be done by God inspiring and natural guidance (Tabatabai, 1414). Quran specifies a variety of universe beauties and encourages men to understand and exploit them. Of questions such as:

The beauty of the sky with decorating the stars (Safat, p. 6), the beauty of combining a human and his face (Ghafir, p. 64; Taghabun, p. 3), the beauty of creatures (Nahl, p. 6), the beauty of natural scenery on earth (Hajj, p. 5; Nahl, p. 60).

\section{Discussion}

The beauty of faith: "But God has endeared the faith to you and beautified it in your hearts..." (Hojorat, p. 7) patience Jamil: "Undoubtedly judgment day arrives, so have forgiveness" (Hajr, p. 85). "Wait, waiting is good" (Ma'arij, p. 5). Holy Quran knows the beauty of the earth as a mean to test human and he says, "We made everything on the earth an embellishment for it, to test who is better in action" (Kahf, p. 7), and on the other hand, it denounces any aesthetic concerns, such as: love, lust (Al Emran, p. 14), the life of the world to unbelievers (Baqarah, p. 212), the wicked malfunction (Mohammad, p. 14), wasters acting (Yunes, p. 12) and the beauty of women for non-mahram (Noor, p. 31).

Second. The need for goodness is the other needs of the human spirit that some effects of it are in two-ways, namely, the giving of good deed to others and getting it from them. Holy Quran has presented a complete definition of good deed, calls people explicitly to it: kindness is not just face (in prayer) to the East and to the West, but kindness is who has believed God and the judgment day and the angels and the book, and the prophets, and has helped his relatives and orphans and the needy and slaves, pray the God and pay the charity and (also) those who are commitment and loyal and show preserve against denial and diseases and in the field war, these are people who are telling the truth and they are pieties (Bagarah, p. 177).

According to this verse, kindness is not facing towards the east or west of our worship, but that is a very broad concept that includes all dogmas and many worship and moral virtues such as faithfulness, patience and endurance. The Quran considers it after worshiping of God and avoiding polytheism, as the most important duty of man in the correct directing to this important psychological need. It introduces giving kindness based on one classification: Serve the God and choose nothing as his partner and be kind with your parents, relatives and orphans, the needy, and the neighbor of relatives and unknown neighbors and partners through the passenger and your servants. Surely, Allah does not love the arrogant and pride (Nisa, p. 36).

The Holy Quran calls on everyone to cooperate for the good and prevents cooperating with evil in sin and the enemy (Maedeh, p. 2). In the Holy Quran view, reaching the position of charity depends on the charity of what human interest (AleEmran, p. 92). Quran blames people who call others to goodness, but forget themselves (Baqarah, p. 44) and asks the believers to speak of goodness and piety in their speech, and prevents to deal with the guilt, hostility, and disobedience to the Prophet (Mojadeleh, p. 9).

Third. A desire of immortality is another need of the human spirit that stems from his lives angles. This tendency in humans will conflict him is whatever endangered his life. Fear and escape from the death are this kind, "Surely the death that you escape from which you will meet it" (Jomaa, p. 8). In the Quran, faith in the hereafter and practical 
efforts to achieve eternal bliss are the main solutions to meet these basic desires. Quran states the truth of the language of the believer from Pharaoh's people: "O my people, this worldly life is only something insignificant, and in fact, it is the abode of the Hereafter that is stable" (Ghafer, p. 39).

Quran blames the believers' attachment to worldly life and their neglect of sustainable hereafter life, counts the world wealth invaluable (Tobeh, p. 38). In Quran thinking, the universe is a mirage and an amusement tool and human play tool, and therefore, it cannot answer his spiritual tendency to eternality. Against it, the hereafter world is a real life that could answer this need correctly: The life of this world is nothing but fun and games; and the Hereafter is the real life, if they but knew (Spider, p. 64).

Fourth. Worship motivation is the effect of human spirit that is rooted in human nature. A human finds a motivation in the depths of human existence, which forces him to research and think about the origin of the world and pray and problem solving and rely him. He asks help during problems, and basically he searches his security and peace in support and trust in him (Nejati, 2007, p. 65). This is what the Qur'an refers to the righteous religion and the nature of God and calls man to it: So come to this religion, the nature that God has molded for the people. A stable religion is this, but most people do not know (Rom, p. 30).

The Quran, in response to the emotional motivation, calls people to worship God sincerely and warns them in this worship of any evil "Pray God and do not choose any partner for him" (Nesa, p. 36). The Holy Qur'an repeatedly mentions the fact that there is no God except Allah in the universe that people could choose him as god and worship and serve him (Araf, pp. 65-73, p. 85; Hood, p. 50, p. 61, p. 84). Worshiping of God is the only direct way that the Qur'an emphasized (Maryam, p. 36; Zukhruf, p. 64; AleEmran, p. 51).

The Quran leads the intrinsic motivation of people to worship the one God, determines certain forms of worshiping for this purpose, and banns the aggression of them. A list of this format is as follows: 1) Prayer, 2) Fast, 3) Zakat, and 4) Hajj. Many verses are dedicated to legislation and explain these things. The highest form of worship is prayer, the Quran introduces it as prostitution forbidden, and Zikrullo Akbar: "Prayer prevents (people) from corruption and evil, but the remembrance of Allah is the greatest" (Ankabut, p. 45).

What happened was a brief of what we can understand from the Qur'an verses on the part of the main physiological needs, psychological and spiritual. The author also knows that objective responses of the Quran to a variety of human needs is much broader and more precise than that is concerned in this article, but since the foundation of this article is brevity, only the outline the master plan of the Quran is concerned and the details of which are to be transferred to another chance.

Although physical, psychological and spiritual needs, over time, have not changed, but the flow of time makes new needs for human life: 1) it creates methods and new forms to meet the fixed needs. 2) It creates new issues, which were unprecedented.

In the face of first type changes, what is needed is awareness and insure the legitimacy or illegitimacy, to apply them to meet the constant needs of human, and in the face of second type changes, the basic requirement is to gain practical and objective solutions of Quran on each of the new issues. Studying the verses, hadiths and religious scholars' comments on the subject has followed a great result that solutions of Quran about how to deal with the needs, is summarized in three fundamental ways: 1) the interior of the Quran, 2) unbreakable bond of Quran and progeny, 3) Methodological approach in the Quran.

\section{Acknowledgements}

These solutions are so comprehensive that, if a proper attention is given to them, no needs of human needs will be unanswered up to the end of the world. These infrastructure solutions will flow and bring the speech the Quran, as the latest version of divine revelation in human life, and put the mind and human life, in the divine revelation continuous rainfall. Scrutiny of these solutions is out of the breadth and scope of the present article; hence, it needs to refer to other sources.

\section{References}

Carver, C., \& Michael, F. (1996). Theories of personality. Deputy culture of Astan Quds Razavi.

Cox, W., \& Ruth, B. (2007). Dress history (Shirin, B., Tran.). Tehran, Toos.

Holy, Q., \& Abu Torabi, A. (2007). Criticizing disorder criteria in psychology. Qom, Imam Khomeini Education and Research Institute (RA).

Ibn, M. (1996). Lisan al-Arab. Beirut, Dar Sader.

Jafari, M. T. (2005). The Quran reasonable rational life. Institute for Compilation and Publication of Allameh Jafari, Tehran. 
Kalantari, I. (2003). The Quran and how to meet the needs of the time. Qom: Publications Office of Education.

Khodapanahi, M. K. (2008). Motivation and excitement. Tehran, Samt.

Makarem, S. N. (2002). Commentary sample. Tehran, Daralkotob Islamiyah.

Marefat, M. H. (1995). Congress reviews the fundamentals of jurisprudence Collected Works of Imam Khomeini. Institute for Compilation and Publication of Imam Khomeini, Tehran.

MesbahYazdi, M. T. (2009). Quran education. Qom, Imam Khomeini Education and Research Institute (RA).

Motahari, M. (1998). Islam and the circumstances of the time. Tehran, Sadra.

Nejati, M. U. (2007). The Quran and psychology. The translation of the Arab Abbas, Mashhad, Razavi.

Paknejad, S. R. (n.d.). The first university and the last prophet. Tehran, bookstore Islamiyah.

Rashid Reza, M. (n.d.). The interpretation of the Holy Quran (Al). Beirut, Daralfekr.

Sadr, S. M. B. (2006). Economic institutions in Islam.

Sayyid, Q. (1981). Fi Zolalo'l Quran, Beirut, Daralsharq.

Schultz, D. (2007). Theories of personality. Tehran, Arasbaran.

Sobhani, J. (1993). Theology. Qom, Imam Sadeq Institute.

Tabatabaei, S. M. H. (1960). Fixed and variable rules in Islam. Journal of Islam, 9.

Tabatabaei, S. M. H. (1993). Al-Mizan fi Tafsir al-Quran. Qom: Islamic Publications.

Witig, A. (2007). Introduction to Psychology. Mohiuddin Bonab, Tehran, Roshd.

Yusufeli, M. (2009). The Quran and solutions to meet the needs of the times, a graduate thesis and interpretation of the Quran. Qom, Imam Khomeini Higher Education Center.

\section{Copyrights}

Copyright for this article is retained by the author(s), with first publication rights granted to the journal.

This is an open-access article distributed under the terms and conditions of the Creative Commons Attribution license (http://creativecommons.org/licenses/by/4.0/). 